\title{
BAHAYA KONTAMINASI LOGAM BERAT MERKURI (Hg) DALAM IKAN LAUT DAN UPAYA PENCEGAHAN KONTAMINASI PADA MANUSIA
}

\author{
Izza Hananingtyas \\ izzahanafkm@gmail.com
}

\begin{abstract}
ABSTRAK
Produk pangan mentah terutama dari hasil laut memiliki tingkat pencemaran logam berat yang mengkhawatirkan akibat semakin banyaknya bahan pencemar yang masuk dalam lingkungan perairan Indonesia yang berasal dari pembuangan limbah industri di sepanjang wilayah pantai dapat menjadi sumber racun bagi kehidupan perairan. Adanya kandungan logam berat di perairan Laut Jawa, memungkinkan adanya kotaminasi pada ikan laut hasil Laut Jawa yang didistribusikan ke masyarakat. Hal ini tidak sesuai dengan peraturan pemerintah yang mengatur dan melindungi keamanan pangan yaitu PP Nomor 28 tahun 2004 tentang Keamanan, Mutu, dan Gizi Pangan. Penelitian ini bertujuan untuk mengetahui dan mengukur kadar logam berat merkuri $(\mathrm{Hg})$ pada hasil laut di Pantai Utara Jawa dan menjelaskan upaya pencegahan kontaminasi pada manusia. Penelitian ini bersifat deskriptif dengan pendekatan cross sectional study. Akumulasi logam berat di dalam tubuh manusia dalam jangka waktu yang lama dapat mengganggu sistem peredaran darah, urat syaraf dan kerja ginjal. Kadar rata - rata logam berat merkuri (Hg) pada ikan tongkol (Euthynnus sp.) di Pantai Utara Jawa sebesar $0,141 \mathrm{mg} / \mathrm{kg}$. Langkah pengendalian yang dapat diterapkan untuk mencegah bahaya logam berat $\mathrm{Hg}$ yaitu dengan pengendalian pencemaran limbah dari industri yang berlokasi disekitar wilayah perairan Laut Utara Jawa. Upaya pencegahan akumulasi kontaminasi logam berat $\mathrm{Hg}$ pada manusia yaitu mengatur konsumsi ikan laut setiap harinya dengan perhitungan ADI (Acceptable Daily Intake) diperoleh hasil $0,168 \mu \mathrm{g} / \mathrm{kg}$ BB per minggu. Akan tetapi bila konsumsi ikan seseorang melebihi rata-rata konsumsi perhari, dan weekly intake-nya melebihi PTWI (provisional tolerable weekly intake) yang telah ditetapkan WHO, maka dapat berefek negatif pada kesehatan.
\end{abstract}

Kata Kunci : logam berat, mercury, Euthynnus sp, Acceptable Daily Intake

\section{PENDAHULUAN}

Logam - logam berat yang terlarut dalam badan perairan pada konsentrasi tertentu dan berubah fungsi menjadi sumber racun bagi kehidupan perairan. Sebagian besar logam berat masuk ke dalam tubuh organisme air melalui rantai makanan dan hanya sedikit yang diambil air. Logam berat menjadi berbahaya disebabkan proses bioakumulasi. Logam berat dapat terakumulasi melalui rantai makanan, semakin tinggi tingkatan rantai makanan yang ditempati oleh suatu organisme, akumulasi logam berat di dalam tubuhnya juga semakin bertambah. Adanya bioakumulasi pada ikan dan hasil laut akan meningkatkan resiko manusia mengalami proses bioakumulasi logam berat yang besar di dalam tubuhnya. ${ }^{(2)}$ Logam berat menimbulkan efek negatif dalam kehidupan makhluk hidup seperti mengganggu reaksi kimia, menghambat absorbsi dari nutrien-nutrien yang esensial. Logam-logam berat tersebut bila masuk ke dalam tubuh lewat makanan akan terakumulasi secaraterus-menerus dan dalam jangka waktu lama dapat mengakibatkan gangguan sistem syaraf, kelumpuhan, dan kematian dini serta penurunan tingkat kecerdasan anak-anak. ${ }^{(1)}$.

Logam-logam berat tersebut bila masuk ke dalam tubuh lewat makanan akan terakumulasi secara terus-menerus dan dalam jangka waktu lama dapat mengakibatkan gangguan sistem syaraf, kelumpuhan, dan kematian dini serta penurunan tingkat kecerdasan anak-anak. Adanya kandungan logam berat $\mathrm{Hg}$ di perairan Laut Jawa, memungkinkan adanya kotaminasi pada ikan laut hasil produksi Laut Jawa. Sebagaimana telah diketahui bahwa logam berat merkuri merupakan logam yang memiliki toksisitas yang sangat tinggi dan banyak dihasilkan oleh sebagai limbah industri. Keberadaan logam di lingkungan yang melebihi batas aman merupakan indikasi dari pencemaran lingkungan dari kegiatan manusia seperti kegiatan industri-industri yang menghasilkan limbah logam berat. Adanya kontaminasi logam berat pada ikan laut yang didistribusikan ke masyarakat sebagai konsumen ini menyimpang dari peraturan pemerintah yang mengatur dan melindungi keamanan pangan yaitu Peraturan Pemerintah Nomor 28 tahun 2004 tentang Keamanan, Mutu, dan Gizi Pangan. Hal ini menjadi kepentingan peneliti untuk memilih ikan tongkol (Euthynnus sp.) yang berasal dari Pantai Utara Jawa untuk diteliti. 
Mengingat bahayanya akumulasi logam berat dalam lingkungan dan efek buruknya pada kesehatan, konsumen perlu pengetahuan tentang logam berat, sumber dan distribusi logam berat di lingkungan, mekanisme kontaminasi logam berat pada tubuhmanusia, serta cara pencegahan akumulasinya.

\section{Tujuan Penelitian}

Tujuan umum penelitian ini adalah untuk mengetahui dan mengukur kandungan logam berat Hg yang terkadandung pada ikan tongkol (Euthynnus sp.) di Pantai Utara Jawa. Sedangkan tujuan khususnya adala mengukur dan membandingkan kadar logam berat $\mathrm{Hg}$ pada ikan tongkol yang ada di Pantai Utara Jawa dengan batas maksimum logam berat dalam makanan yang ditetapkan oleh Peraturan Badan Pengawas Obat dan Makanan tahun 2009 dan Standar Nasional Indonesia tahun 2009, serta menentukan alternativ cara pencegahan pencemaran logam berat $\mathrm{Hg}$ pada ikan.

\section{METODE PENELITIAN}

Penelitian ini bersifat deskriptif dengan pendekatan cross sectional study. ${ }^{(4)}$ Populasi dalam penelitian ini adalah hasil laut berupa ikan tongkol dari Pantai Utara Jawa, yaitu: Kendal, Rembang, Tuban, Batang, dan Jepara, dengan besar sampel 10 ekor ikan tongkol yang penelitian ini diambil secara purposive sampling. Analisis data dilakukan secara deskriptif yaitu memberikan diskripsi tentang sampel yang diteliti melalui data sampel sebagaimana adanya. Hasil pemeriksaan diuraikan dengan statistic deskriptif, yaitu dalam bentuk table untuk menggambarkan hasil identifikasi kandungan logam berat $\mathrm{Hg}$ pada ikan tongkol (Euthynnus sp.), kemudian ditinjau dari faktor-faktor yang mempengaruhi hasil identifikasi kandungan logam berat $\mathrm{Hg}$ pada ikan tongkol (Euthynnus sp.).

\section{HASIL PENELITIAN DAN PEMBAHASAN}

Hasil pengukuran kadar logam berat timbal $\mathrm{Hg}$ pada ikan tongkol di Pantai Utara Jawa tercantum dalam tabel 1 sebagai berikut:

Tabel 1. Kadar Logam Berat Hg pada Ikan Tongkol

\begin{tabular}{|c|c|c|c|}
\hline $\begin{array}{c}\text { Tahap Pengambilan } \\
\text { Sampel }\end{array}$ & Asal Ikan & $\begin{array}{c}\text { No } \\
\text { Sampel }\end{array}$ & Kadar Hg (mg/kg) \\
\hline \multirow{4}{*}{ Tahap I } & Kendal & 1 & 0,070 \\
\cline { 2 - 4 } & Rembang & 2 & 0,180 \\
\cline { 2 - 4 } & Tuban & 3 & 0,120 \\
\cline { 2 - 4 } & Batang & 4 & 0,080 \\
\cline { 2 - 4 } & Jepara & 5 & 0,080 \\
\hline \multirow{5}{*}{ Tahap II } & Kendal & 6 & 0,120 \\
\cline { 2 - 4 } & Rembang & 7 & 0,220 \\
\cline { 2 - 4 } & Tuban & 8 & 0,310 \\
\cline { 2 - 4 } & Batang & 9 & 0,090 \\
\cline { 2 - 4 } & Jepara & 10 & 0,140 \\
\hline \multirow{5}{*}{ Rata-rata } & & & 0,141 \\
\hline
\end{tabular}

Dari tabel di atas diketahui bahwa rata-rata kadar merkuri yang terdapat dalam ikan tongkol adalah $0,141 \mathrm{mg} / \mathrm{kg}$ dengan standar deviasinya adalah $0,07622 \mathrm{mg} / \mathrm{kg}$. Dari data tersebut dapat diketahui bahwa seluruh sampel ikan tongkol telah terkontaminasi logam berat $\mathrm{Hg}$. Kadar rata-rata logam berat merkuri pada ikan tongkol secara keseluruhan dari 10 sampel ikan tongkol yaitu sebesar $0,5 \mathrm{mg} / \mathrm{kg}$. Walaupun tidak melebihi batas maksimum yang diperbolehkan oleh Peraturan Badan Pengawas Obat dan Makanan tahun 2009 maupun Standar Nasional Indonesia (SNI:7387) tahun 2009, tetapi adanya akumulasi logam Hg akibat dari pengonsumsian ikan laut oleh masyarakat sangat mengkhawatirkan.

Adanya beberapa sampel ikan tongkol yang mengandung logam berat $\mathrm{Hg}$ menunjukkan adanya penyimpangan dari standardisasi keamanan pangan nasional dan standardiisasi penilaian kesesuaian (conformity assessment) untuk meningkatkan daya saing produk nasional, mengingat Standar Nasional Indonesia (SNI) dibuat untuk melindungi produsen, konsumen, dan masyarakat dari aspek keamanan, dalam transaksi pasar global. Adanya penyimpangan cemaran logam berat dalam makanan dapat dapat berefek negatif pada kesehatan manusia yang 
mengkonsumsinya secara berlebih. Adanya kadar logam berat pada bahan olahan makanan berdasarkan SNI 7387 tahun 2009 ini dapat berdampak tidak diterimanya produksi hasil laut dari Indonesia di pasar global.

\section{Sumber Pencemaran Logam Berat Hg di Laut}

Polutan merkuri masuk ke dalam lingkungan akuatik, bisa bersumber dari udara maupun kegiatan antropogenik di daratan, seperti terlukis pada gambar 1 berikut: ${ }^{(3)}$

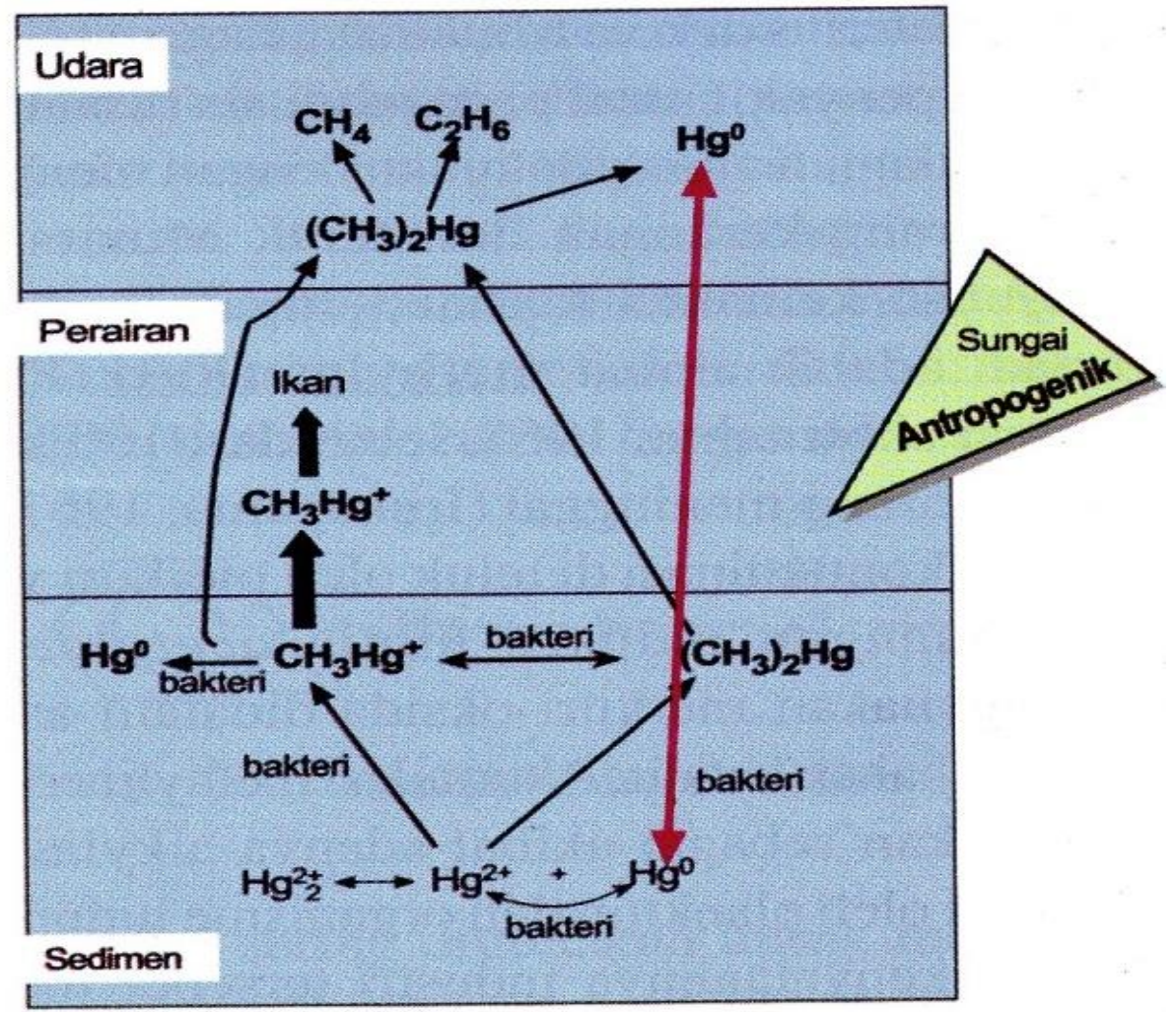

Gambar 1. Siklus Biological Merkuri ${ }^{(3)}$

Logam-logam tersebut diketahui dapat tertimbun di dalam tubuh suatu organisme, dan tetap tinggal di tubuh dalam ikatan methyl mercury dan akan berdiam dalam jangka waktu lama sebagai racun yang terakumulasi. Di alam merkuri sebagai mineral tetapi kandungan sedikit saja. Umumnya ada bersama dengan sulfid: cinnabar dan metacinnabar. ${ }^{(3)}$ Logam-logam tersebut diketahui dapat tertimbun di dalam tubuh dalam ikatan metil mekuri, dan akan berdiam dalam jangka waktu lama sebagai racun yang terakumulasi. Merkuri terdistribusi luas di bebatuan, tanah, udara, dan perairan.

Beberapa bentuk merkuri yang masuk ke dalam ekosistem perairan laut. ${ }^{(3)}$

1) Merkuri anorganik yang berasal dari air hujan atau aliran sungai yang bersifat stabil pada $\mathrm{pH}$ rendah

2) Merkuri organik antara lain fenil merkuri $\left(\mathrm{C}_{6} \mathrm{H}_{5} \mathrm{Hg}\right)$, metal merkuri $\left(\mathrm{CH}_{3} \mathrm{Hg}\right)$, alkoksil merkuri , atau metoksi etil merkuri.

3) Terikat dalam bentuk suspended soil sebagai $\mathrm{Hg}$.

Merkuri masuk ke perairan melalui hujan yaitu berkisar antara $0,0008-1,45 \mu \mathrm{g} / 1 \mathrm{Hg}$. Akan tetapi masuknya $\mathrm{Hg}$ ke dalam perairan sebagian besar akibat adanya pencemaran. ${ }^{(5)}$ Kadar merkuri yang tinggi pada perairan umumnya diakibatkan oleh buangan industri (industrial wastes) dan akibat sampingan dari penggunaan senyawa-senyawa merkuri di bidang pertanian. Merkuri dapat berada dalam bentuk metal, senyawa-senyawa anorganik dan senyawa organik. ${ }^{(6)}$ Fluktuasi merkuri di lingkungan laut, terutama di daerah estuarin dan daerah pantai ditentukan oleh proses sedimentation, floculation dan reaksi adsorpsi desorpsi. ${ }^{(7)}$ Transfer dan transformasi merkuri dapat dilakukan oleh phytoplankton dan bakteri, disebabkan kedua organisme tersebut relatif mendominasi suatu perairan, dan juga oleh rumput laut. Bakteri dapat merubah merkuri menjadi methyl merkury, dan membebaskan merkuri dari sendimen. Dalam kegiatannya bakteri membutuhkan bahan organic atau komponen-komponen karbon, nitrogen dan posphat sebagai makanannya. ${ }^{(6)}$ 
Methyl mercury yang terbentuk dalam sediman bersifat tidak stabil, sehingga mudah dilepaskan ke dalam perairan yang kemudian diakumulasi oleh hewan maupun timbuh-tumbuhan air. Merkuri mempunyai kemampuan yang tinggi untuk ikut proses bioakumulasi pada organisme laut. Hal ini menyebabkan merkuri akan terakumulasi pada jaringan tubuh makhluk hidup. Pada banyak kasus bioakumulasi merkuri ini berlanjut mengikuti rantai makanan. ${ }^{(6)}$

Pergerakan lokal unsur merkuri di perairan umum dapat dilihat pada gambar 2 berikut ini:

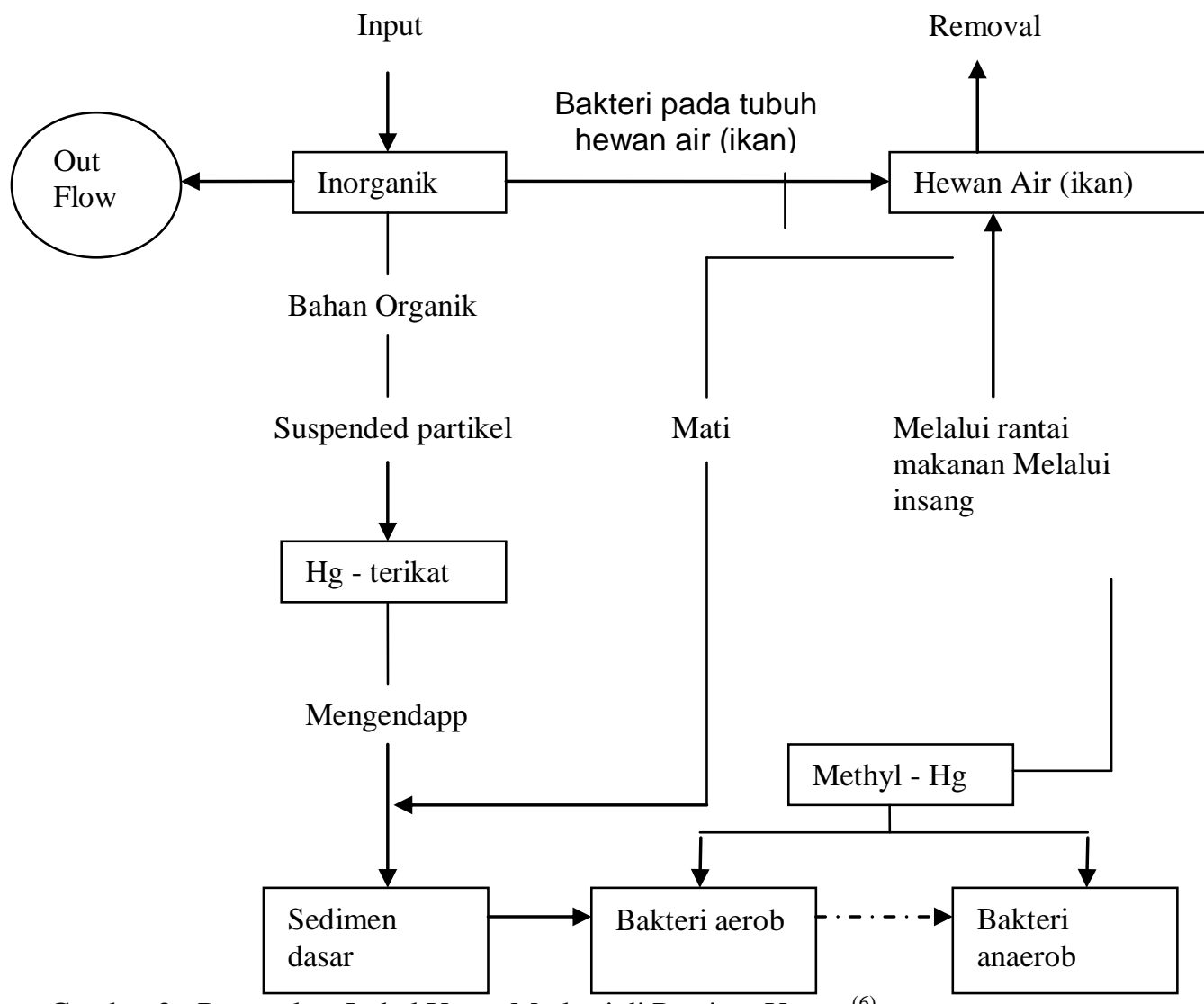

Gambar.2. Pergerakan Lokal Unsur Merkuri di Perairan Umum ${ }^{(6)}$

\section{Mekanisme Kontaminasi Logam Berat Hg pada Ikan}

Kandungan logam $\mathrm{Hg}$ pada ikan tongkol ditentukan oleh penyerapan ikan tongkol selama hidup di air yang juga terkait dengan jumlah logam berat $\mathrm{Hg}$ yang terlarut dalam air dan rantai makanannya. Polutan merkuri masuk ke dalam lingkungan akuatik, bisa bersumber dari udara maupun kegiatan antropogenik di daratan. Pencemaran perairan oleh merkuri mempunyai pengaruh terhadap ekosistem setempat yang disebabkan oleh sifatnya yang stabil dalam sendimen, kelarutannya yang rendah dalam air dan kemudahannya diserap dan terkumpul dalam jaringan tubuh organisme air, baik melalui proses bioaccumulation maupun biomagnification yaitu melalui food chain ${ }^{(30)}$ Di lapisan permukaan laut, kandungan merkuri berkisar $0,1 \mu \mathrm{g} / \mathrm{l}$, semakin ke dalam laut akan meningkat kandungannya hingga menjadi $0,15 \mu \mathrm{g} / \mathrm{l}$ sampai $0,27 \mu \mathrm{g} / \mathrm{l}$. Hal ini dikarenakan adanya penyerapan merkuri oleh plankton di permukaan laut dan terjadi perpindahan akumulasi ke dalam laut. ${ }^{(5)}$

Merkuri mempunyai kemampuan yang tinggi untuk proses bioakumulasi pada organisme laut. Hal ini menyebabkan merkuri akan terakumulasi pada jaringan tubuh makhluk hidup. Pada banyak kasus, bioakumulasi merkuri ini berlanjut mengikuti rantai makanan. Dengan demikian, predator mempunyai konsentrasi merkuri lebih tinggi dibanding organisme dimakannya. ${ }^{(6)}$ Ikan tongkol merupakan jenis ikan predator yang hidup di lapisan permukaan laut ataupun di laut dalam. ${ }^{(15)}$ Oleh karena hal inilah kandungan merkuri dalam ikan tongkol lebih besar daripada ikan kecil lainnya.

Pada penelitian yang dilakukan oleh Zodape (2011) pada ikan laut di Mumbai-India menyatakan bahwa penyerapan logam berat oleh ikan lebih besar terjadi pada jaringan seperti pada hati dan insang daripada penyerapan pada daging ikan, sehingga kandungan logam berat $\mathrm{Hg}$ pada daging ikan hanya sebagian kecil yang terdeteksi. ${ }^{(20)}$ Adanya 
kandungan logam berat yang lebih tinggi pada insang dan hati ini disebabkan karena yang masuk ke dalam tubuh lebih banyak terserap dalam jaringan lunak (ginjal dan hati) daripada yang terserap ke jaringan lainnya. Hal ini senada dengan penelitian Sjahrul yang menyatakan bahwa, urutan kandungan logam berat pada organ tubuh ikan mulai dari yang tertinggi sampai yang terendah adalah pada organ isi (hati dan ginjal), tulang, kulit, dan daging. ${ }^{(21)} \mathrm{Hal}$ ini berarti bahwa kandungan tertinggi kontaminan logam berat selain pada organ isi dalam, juga pada tulang dan kulit. Oleh karena itu, masyarakat diharapkan lebih berhati-hati dalam memilih bagian ikan yang akan dikonsumsi, yaitu cukup mengkonsumsi bagian daging ikannya saja.

\section{Mekanisme Kontaminasi Logam Berat Hg pada Manusia}

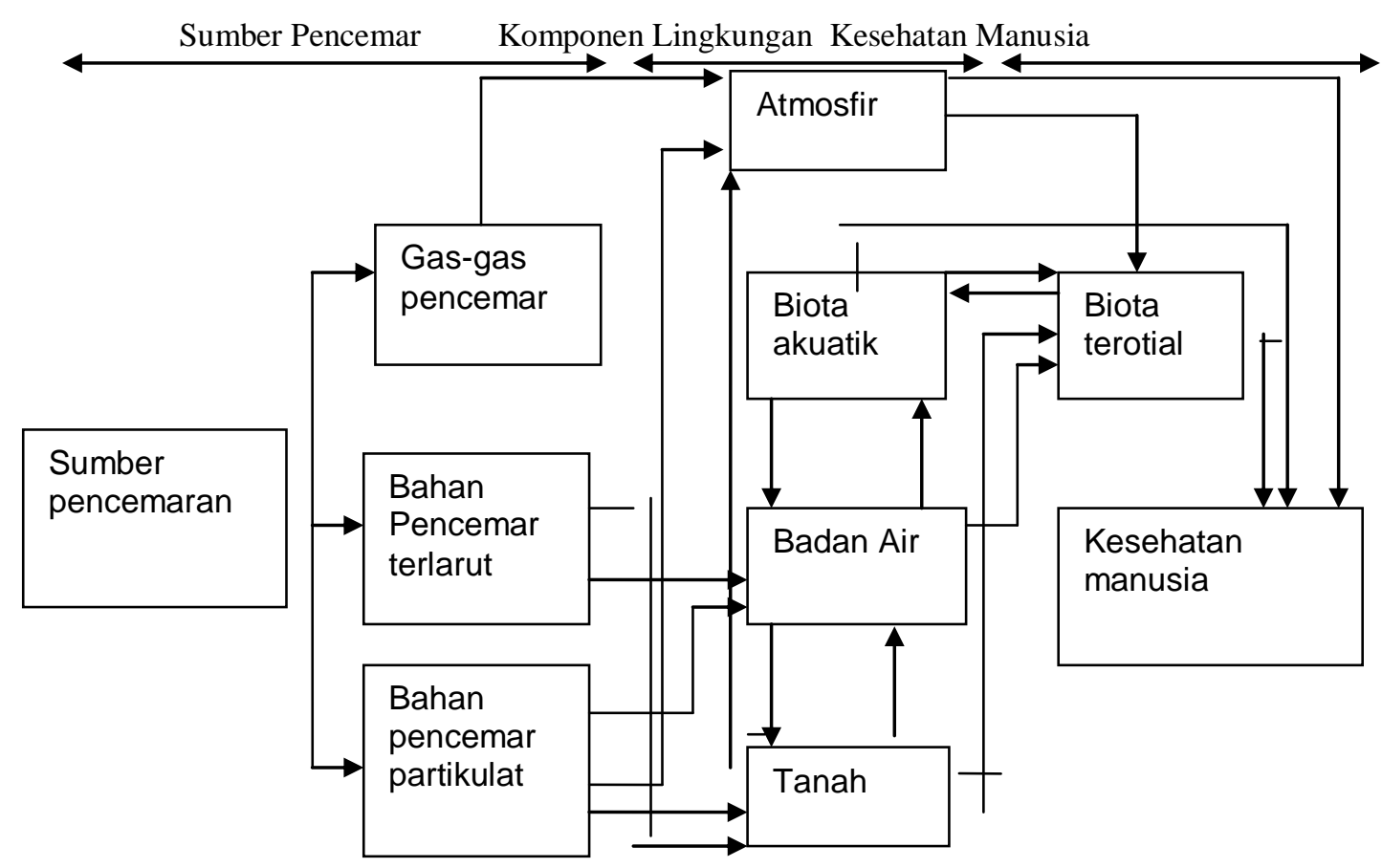

Gambar 3. Bagan Pengaruh Beberapa Jenis Bahan Pencemar terhadap Lingkungan Perairan hingga mempengaruhi Kesehatan Manusia ${ }^{(8)}$

Risiko toksisitas berarti besarnya kemungkinan zat kimia untuk menimbulkan keracunan. Hal ini tergantung dari besarnya dosis, konsentrasi, lama dan seringnya pemaparan, juga cara masuk dalam tubuh. Mekanisme keracunan dapat terbagi dalam 2 (dua) fase, yaitu fase kinetik dan fase dinamik. Fase kinetik meliputi proses - proses biologi biasa seperti adanya penyerapan, penyebaran dalam tubuh, metabolisme dan proses pembuangan atau ekskresi. Adapun pada fase dinamik meliputi semua reaksi biokimia yang terjadi dalam tubuh, berupa katabolisme dan anabolisme yang melibatkan enzim - enzim. ${ }^{(2)}$ Mekanisme keracunan oleh logam ke dalam 3 (tiga) kategori, yaitu: ${ }^{(2)}$

1) Memblokir atau menghalangi kerja gugus fungsi biomolekul yang esensial untuk proses-proses biologi, seperti protein dan enzim.

2) Menggantikan ion-ion logam yang terdapat dalam molekul terkait.

3) Mengadakan modifikasi atau perubahan bentuk dari gugus aktif yang dimiliki oleh biomolekul.

Risiko apabila mengkonsumsi pakan mengandung bahan toksik setiap harinya adalah akumulasi bahan toksik tersebut sehingga konsentrasi dalam tubuh hewan lebih tinggi dari pada konsentrasi yang terkandung dalam pakan yang dikonsumsi. Bila seekor hewan mengandung bahan toksik dikonsumsi hewan lainnya maka hewan kedua memiliki konsentrasi bahan toksik lebih tinggi dari hewan pertama, demikian juga hewan ketiga yang memakan hewan kedua, rangkaian proses tersebut disebut "food chain". (2)

\section{Bahaya Logam Berat Hg dalam Tubuh Manusia}

Apabila masyarkat mengkonsumsi ikan tongkol secara berlebih secara terus menerus dan melebihi batas aman PTWI yang telah ditetapkan oleh FAO atau WHO, yaitu mengkonsumsi tidak lebih dari 0,3 mg per minggu, maka dapat menyebabkan timbulnya efek negatif dari toksisitas merkuri dalam tubuh manusia yang dapat mempengaruhi kesehatannya. 
Sebagian besar logam merkuri akan terakumulasi dalam ginjal, otak, hati dan janin. Efek toksik $\mathrm{Hg}$ berkaitan dengan susunan syaraf yang sangat peka terhadap $\mathrm{Hg}$ dengan gejala pertama adalah perestesia, lalu ataksia, disartria, ketulian, dan akhirnya kematian. Merkuri bisa menghambat pelepasan GnRH oleh kelenjar hipotalamus dan menghambat ovulasi sehingga terjadi akumulasi $\mathrm{Hg}$ pada korpus loteum. ${ }^{(9)}$

Toksisitas merkuri organik sangat luas, yakni mengakibatkan disfungsi blood brain barrier, merusak permeabilitas membran, menghambat beberapa enzim, menghambat sintesa protein, dan menghambat penggunaan substrat protein. Namun demikian, alkil merkuri atau methyl merkuri tidak mengakibatkan kerusakan membrane mukosa sehingga gejala toksisitas merkuri organik lebih lambat dibandingkan merkuri anorganik. ${ }^{(3)}$ Gejala toksisitas merkuri organik meliputi kerusakan sistem saraf pusat berupa anoreksia, ataksia, dismetria, gangguan pandangan mata yang bisa mengakibatkan kebutaan, gangguan pendengaran, konvulsi, paresis, koma dan kematian. ${ }^{(3)}$

\section{Pengendalian Cemaran Logam Berat Hg pada Ikan Laut}

Langkah pengendalian yang dapat diterapkan untuk mencegah bahaya dan menghilangkan bahaya tersebut, sesuai metode HACCP maka critical control point yang dapat diterapkan adalah adanya pengendalian pencemaran limbah dari industri-industri yang berlokasi disekitar wilayah perairan Laut Utara Jawa. Pengendalian pencemaran yang dapat diterapkan adalah seperti pengolahan limbah sebelum dibuang ke badan air. Selain itu industri - industri yang membuang limbahnya ke lingkungan harus berwawasan lingkungan, sehingga limbah yang dibuang ke badan air masih dalam kategori aman dan tidak melebih ambang batas.

Hazard Analysis, adalah analisis bahaya atau kemungkinan adanya risiko bahaya yang tidak dapat diterima. Bahaya disini adalah segala macam aspek mata rantai produksi pangan yang tidak dapat diterima karena merupakan penyebab masalah keamanan pangan. Bahaya tersebut meliputi: ${ }^{(9)}$

1. Keberadaan yang tidak dikehendaki dari pencemar biologis, kimiawi, atau fisik pada bahan mentah.

2. Pertumbuhan atau kelangsungan hidup mikroorganisme dan hasil perubahan kimiawi yang tidak dikehendaki (misalnya nitrosamin) pada produk antara atau jadi, atau pada lingkungan produksi.

3. Kontaminasi atau kontaminasi ulang (cross contamination) pada produk antara atau jadi, atau pada lingkungan produksi.

Critical Control Point (CCP atau titik pengendalian kritis), adalah langkah dimana pengendalian dapat diterapkan dan diperlukan untuk mencegah atau menghilangkan bahaya atau menguranginya sampai titik aman. Titik pe ngendalian kritis (CCP) dapat berupa bahan mentah, lokasi, praktek, prosedur atau pengolahan dimana pengendalian dapat diterapkan untuk mencegah atau mengurangi bahaya. ${ }^{(19)}$

Berdasarkan European Committee for Standadisation, sistem HACCP didasarkan pada 7 prinsip berikut ini:

1. Melakukan suatu analisis potensi bahaya

2. Menentukan Titik-titik Pengendalian Kritis atau Critical Control Points (CCP)

3. Menyusun batas-batas kritis

4. Menyusun suatu sistem untuk mengawasi pengendalian CCP.

5. Menyusun tindakan-tindakan perbaikan yang harus diambil ketika pengawasan menunjukkan bahwa suatu titik pengendalian kritis (CCP) berada diluar kendali.

6. Menyusun prosedur pengecekan ulang untuk memastikan bahwa sistem HACCP dapat bekerja dengan efektif.

7. Menyusun dokumentasi yang berhubungan dengan semua prosedur dan catatan-catatan yang sesuai untuk prinsip-prinsip ini beserta aplikasinya

\section{Upaya Pencegahan Kontaminasi Logam Berat pada Manusia}

Konsumsi ikan tongkol yang berlebih juga membahayakan kesehatan. Hal ini mengingat sifat merkuri yang merupakan racun yang dapat terakumulasi. Merkuri berbentuk metilionin dalam tubuh manusia. Metilionin mampu mengikat logam-logam berat dengan sangat kuat khususnya merkuri (Hg), kadmium (Cd), perak (Ag), dan seng (Zn). Logam berat dapat diabsorbsi dan diakumulasikan dalam jaringan hidup.

Hasil pengukuran logam berat $\mathrm{Hg}$ pada ikan tongkol yang telah didapat, apabila dihubungkan dengan hasil penelitian lain, yaitu Waqar Ashraf (2006) pada ikan tuna di Saudi Arabia diketahui bahwa kandungan $\mathrm{Hg}$ menunjukkan hasil antara $0,18 \mathrm{mg} / \mathrm{kg}$ sampai $0,86 \mathrm{mg} / \mathrm{kg}$, menunjukkan hasil masih di bawah batas aman yang telah ditetapkan oleh Food and Agricultural Organization / World Health Organization (FAO/WHO) yaitu 
mengkonsumsi tidak lebih dari $0,3 \mathrm{mg}$ per minggu. Ini berarti hasil pengukuran logam berat $\mathrm{Hg}$ pada ikan tongkol dari perairan Laut Jawa masih lebih rendah dari ikan tuna di perairan Laut Arab, sehingga dapat diketahui bahwa kandungan $\mathrm{Hg}$ pada ikan tongkol masih di bawah batas aman dari FAO/WHO. Ini berarti masyarakat boleh mengkonsumsi ikan laut asalkan mengkonsumsi tidak lebih dari 0,3 mg per minggu. ${ }^{(19)}$

Apabila diasumsikan tingkat konsumsi ikan pada masyarakat Indonesia rata-rata per hari adalah 10 gram per hari, dan rata-rata berat badannya adalah $60 \mathrm{~kg}$, maka Daily Intake pada masyarakat dapat dihitung sebagai berikut:

$$
\begin{aligned}
& \mathrm{DI}=\mathrm{C}(\mathrm{Hg})(\mu \mathrm{g} / \mathrm{g}) \times \mathrm{I}(\mathrm{g} / \text { orang/hari }) \\
& \text { Body Weight }(\mathrm{kg}) \\
& \text { DI = Daily Intake } \\
& \mathrm{C}(\mathrm{Hg})=\text { Concentration in fish }(\mu \mathrm{g} / \mathrm{g}) \\
& \text { I } \quad=\text { Mean Fish Consumption (g/orang/hari) } \\
& \mathrm{DI}=0,141(\mu \mathrm{g} / \mathrm{g}) \times 10(\mathrm{~g} / \text { orang/hari })=0,024 \mu \mathrm{g} / \mathrm{kg} \mathrm{BB} / \mathrm{hari} \\
& 60(\mathrm{~kg})
\end{aligned}
$$

Setelah diketahui Daily Intake-nya maka dapat diketahui Weekly Intake-nya sebesar :

Weekly Intake $=$ Weekly Intake x $7=0,024$ x $7=0,168 \mu \mathrm{g} / \mathrm{kg} \mathrm{BB} / \mathrm{minggu}$

Dari perhitungan diatas diketahui konsumsi ikan tongkol perminggunya sebesar $0,168 \mu \mathrm{g} / \mathrm{kg} \mathrm{BB}$ per minggu , jadi bila dibandingkan dengan PTWI (provisional tolerable weekly intake) yang telah ditetapkan oleh WHO 0,3 $\mu \mathrm{g} / \mathrm{kg}$ per minggu, maka masih tergolong aman. Akan tetapi bila konsumsi ikan seseorang melebihi rata-rata konsumsi perhari, dan weekly intake-nya melebihi PTWI (provisional tolerable weekly intake) yang telah ditetapkan WHO, maka dapat berefek negative pada kesehatan.

\section{KESIMPULAN}

Kadar rata - rata logam berat merkuri (Hg) pada ikan tongkol (Euthynnus sp.) di Pantai Utara Jawa sebesar 0,141 $\mathrm{mg} / \mathrm{kg}$ masih di bawah batas aman yang ditetapkan oleh Peraturan BPOM RI tahun 2009 dan SNI 7387 tahun 2009. Upaya pencegahan akumulasi kontaminasi logam berat $\mathrm{Hg}$ pada manusia yaitu mengatur konsumsi ikan laut setiap harinya dengan perhitungan ADI (Acceptable Daily Intake) diperoleh hasil 0,168 $\mu \mathrm{g} / \mathrm{kg} \mathrm{BB}$ per minggu , jadi bila dibandingkan dengan batas toleransi PTWI (provisional tolerable weekly intake) yang telah ditetapkan oleh WHO 0,3 $\mu \mathrm{g} / \mathrm{kg}$ per minggu, maka masih tergolong aman. Akan tetapi bila konsumsi ikan seseorang melebihi rata-rata konsumsi perhari, dan weekly intake-nya melebihi PTWI yang telah ditetapkan WHO, maka dapat berefek negative pada kesehatan.

\section{DAFTAR PUSTAKA}

1. Kusnoputranto, H. Pengantar Toksikologi Lingkungan. Jakarta: Direktorat Jendral Pendidikan Tinggi, 1995

2. Darmono. Lingkungan Hidup dan Pencemaran. Jakarta : Universitas Indonesia, 2001

3. Yulianto. Penelitian Tingkat Pencemaran Logam Berat di Pantai Utara Jawa Teangah. Semarang: Badan Penelitian dan Pengembangan Provinsi Jawa Tengah, 2006, (Online), (http://bkp.deptan.go.id/Artikel.pdf )

4. Notoatmodjo. Metodologi Penelitian Kesehatan. Jakarta : Rineka Cipta, 2005

5. Sivirta, J. Chemical Ecotoxicology. Florida: CRC Press, 2000

6. Budiono. Pengaruh Pencemaran Merkuri Terhadap Biota Air. Bogor: IPB, 2003

7. Sorensen. Metal Poisoning in Fish. Florida: CRC Press, 2000

8. Wardhana, W. Dampak Pencemaran Lingkungan. Yogyakarta: Andi Offset. 1995

9. Widowati. Efek Toksik Logam. Yogyakarta : Andi Yogyakarta. 2008

10. Palar, H. Pencemaran dan Toksikologi Logam Berat. Jakarta: Rineka Cipta, 2008

11. Rompas. Toksikologi Kelautan. Jakarta: Sekretariat Dewan Kelautan Indonesia, 2010

12. Sivaperumal. Heavy Metal Concentration in Fish, Shellfish, and Fish Products from Internal Market of India vis-à-vis Internasional Standards. Food Chemistry 102 (2007) 612-620. 2006 
13. Wulandari. Pola Sebaran Logam Berat Pb dan Cd di Muara Sungai Babon dan Seringin di Semarang. Jurnal Ilmu Kelautan. 2008. Vol.13(14):203-208. (http://isjd.pdii.lipi.go.id/admin/jurnal/13408203208.pdf)

14. Yulianto. Penelitian Tingkat Pencemaran Logam Berat di Pantai Utara Jawa Teangah. Semarang: Badan Penelitian dan Pengembangan Provinsi Jawa Tengah, 2006, (Online), (http://bkp.deptan.go.id/Artikel.pdf)

15. Peraturan Badan Pengawas Obat dan Makanan Republik Indonesia Nomor HK.00.06.1.52.4011 tahun 2009 tentang Penetapan Batas Maksimum Cemaran Mikroba dan Kimia dalam Makanan, 2009

16. Budiharo. Studi Pengaruh Bulking Agents pada Proses Bioremediasi Lumpur Minyak. Jurnal Purifikasi. Vol.8. N0.1. 2007

17. Ginting. Pemanfaatan Limbah (Oil Sludge) sebagai Bahan Utama dalam Pembuatan Konstruksi Paving Block. Tesis. 2009

18. Warlina. Pencemaran Air: Sumber, Dampak dan Penangguilangannya. Bogor: Pasca Sarjana IPB, 2004

19. Ashraf. Levels Of Selected Heavy Metals in Tuna. The Arabian Journal for Science and Engineering, Vol.31, No.31. 2006.

20. Zodape. Contamination of heavy metals inseafood marketed from Ville Parle and Dadar Markets of suburban areas of Mumbai,India. International Journal of Environmental Sciences. Vol.1. No.6. 2011.

21. Sjahrul. Studi Konsentrasi $\mathrm{Cd}, \mathrm{Cu}, \mathrm{Fe}$, dan Pb dalam Organ Tubuh Udang Windu dan Ikan Bandeng. (Online). (http://e-jurnal.perpustakaan.ipb.ac.id/files/BKI99no14msj.pdf) 